\title{
Recent findings on epigenetic gene abnormalities involved in uterine cancer (Review)
}

\author{
MEGUMI YANOKURA, KOUJI BANNO, YUSUKE KOBAYASHI, \\ HIROYUKI NOMURA, SHIGENORI HAYASHI, EIICHIRO TOMINAGA and DAISUKE AOKI \\ Department of Obstetrics and Gynecology, Keio University School of Medicine, Tokyo 160-8582, Japan
}

Received February 2, 2017; Accepted August 29, 2017

DOI: $10.3892 / \mathrm{mco} .2017 .1428$

\begin{abstract}
Selective aberrant genetic effects that do not depend on abnormal DNA sequences are referred to as epigenetic abnormalities and are involved in carcinogenesis. In uterine cancer, various genes involved in apoptosis, cell cycle, DNA repair, cell proliferation and cell adhesion are abnormally methylated, resulting in gene silencing. Reversal of such epigenetic abnormalities in cancer cells is a potential strategy for cancer therapy, and studies on epigenetic abnormalities and treatment methods in uterine cancer are in progress. These include the evaluation of 5-hydroxymethylcytosine, which is present in cancer tissues at lower levels compared with those in normal tissues, as a prognostic marker in cervical cancer; combination therapy with 5-azacytidine and cisplatin; combination treatment focusing on tumor necrosis factor-related apoptosis-inducing ligand in cervical cancer; studies focusing on DNA mismatch repair in endometrial cancer; and use of a demethylating agent to reactivate tumor suppressor genes and inhibit tumor proliferation. Detection of epigenetic changes using biomarkers may be used for histological classification, evaluation of disease progression and identification of compounds that are able to modulate epigenetic changes and may be useful for uterine cancer treatment.
\end{abstract}

\section{Contents}

1. Introduction

2. Diagnosis of cervical cancer and epigenetic abnormalities

3. Targeting of epigenetic abnormalities in cervical cancer therapy

4. Diagnosis of endometrial cancer and epigenetic abnormalities

5. Targeting of epigenetic abnormalities in endometrial cancer therapy

6. Conclusion

Correspondence to: Dr Kouji Banno, Department of Obstetrics and Gynecology, Keio University School of Medicine, 35 Shinanomachi, Shinjuku-ku, Tokyo 160-8582, Japan

E-mail:kbanno@keio.jp

Key words: epigenetics, cervical cancer, endometrial cancer, DNA methyltransferase, histone deacetylases

\section{Introduction}

Cervical and endometrial cancer rank fourth and fifth, respectively, in cancer prevalence by organ among women worldwide (1). Studies of oncogenic pathways have shown early and frequent DNA methylation, with the extent of this change considered to be related to severity. In both cervical and endometrial cancer, specific genes involved in various pathways are known to be methylated. In cervical cancer, these genes include tumor protein $\mathrm{p} 73$, fragile histidine triad (FHIT), death-associated protein kinase 1 and PRDI-BF and RIZ domain containing 14 in the apoptotic pathway; cyclin A1 (CCNA1) and double $\mathrm{C} 2$-like domain $\beta$ in the cell cycle; adenomatous polyposis coli $(A P C)$ and secreted frizzled-related protein $(S F R P)$ in the $\mathrm{Wnt} / \beta$-catenin pathway; Fanconi anemia, complementation group F, O-6-methylguanine-DNA methyltransferase, human MutL homolog 1 (hMLH1) and CCNA1 in DNA repair; FHIT, retinoic acid receptor- $\beta$ and myelin and lymphocyte in the cell growth pathway; and CXC chemokine receptor 4 and cell adhesion molecule 1, which are involved in cell adhesion (2-21). In endometrial cancer, the following genes are methylated: $A P C$, caspase- 8 , checkpoint with forkhead-associated and ring finger, E-cadherin, $h M L H 1, p 73$, progesterone receptor, phosphatase and tensin homologue deleted on chromosome 10, Ras association domain family 1 isoform A and thrombospondin 2 (22-47). The roles of these methylated genes are listed in Table I for cervical cancer and in Table II for endometrial cancer. Gene silencing caused by methylation may promote cancer progression, and studies on the clinical significance of gene silencing are ongoing.

\section{Diagnosis of cervical cancer and epigenetic abnormalities}

A recent study demonstrated that combined detection of methylated chromosome 3 open reading frame 18, junctional adhesion molecule 3 (JAM3) and ankyrin repeat domain 18C (ANKRD18CP) provided good diagnostic outcomes (48). The sensitivity for lesions of CIN2 or higher was $74 \%$ in this screening, which is comparable with the $79 \%$ sensitivity of the high-risk human papillomavirus (HPV) DNA test. The specificity of this screening was $76 \%$, exceeding the value of $42 \%$ for the high-risk HPV DNA test $(\mathrm{P}<0.05)$. Combined detection using JAM3, glial cell line-derived neurotrophic factor 
family receptor $\alpha 1$ and $A N K R D 18 C P$ has $73 \%$ sensitivity and $77 \%$ specificity, and that using JAM3/ANKRDI8CP has $72 \%$ sensitivity and $79 \%$ specificity, which are also considered as relatively good diagnostic outcomes. Higher specificity is preferable for the prevention of unnecessary follow-up. Furthermore, if HPV vaccination is promoted, the incidence of HPV-negative cervical cancer may increase and the HPV test may become less significant. Therefore, an alternative screening method with a higher specificity for HPV is needed and the methylated markers found in the abovementioned studies are candidates for this screening.

5-Hydroxymethylcytosine $(5 \mathrm{hmC})$ has been shown to be a prognostic marker for squamous cell carcinoma of the cervix (49). $5 \mathrm{hmC}$ is a cytosine modification found in various biological species that is present at high levels in human and murine nerve tissues. $5 \mathrm{hmC}$ is a novel DNA modification marker in mammalian genomes and is involved in DNA demethylation in epigenetic regulation. Tet protein hydroxylates 5-methylcytosine $(5 \mathrm{mC})$ to form $5 \mathrm{hmC}$, and this oxidation pathway is involved in the activation or reduction of gene expression (50). The expression levels of $5 \mathrm{hmC}, 5 \mathrm{mC}$ and $T E T 1$, TET2 and TET3 were determined in squamous cell carcinoma tissues from the uterine cervix in 140 patients and in normal uterine cervix tissues in 40 healthy volunteers. In addition, the prognostic values of $5 \mathrm{hmC}, 5 \mathrm{mC}$ and TET2 were assessed for therapeutic outcomes in squamous cell carcinoma of the cervix. The results demonstrated that $5 \mathrm{hmC}$ is significantly decreased and $5 \mathrm{mC}$ is significantly increased in squamous cell carcinoma of the cervix compared with normal cervical tissues. Furthermore, the expression of TET2, but not that of TET1 or TET3, was decreased in squamous cell carcinoma of the cervix. A reduced level of $5 \mathrm{hmC}$ was associated with a poor outcome for patients with squamous cell carcinoma of the cervix. $5 \mathrm{hmC}$ expression was an independent prognostic factor for event-free and overall survival in these patients, and is likely to be useful as a prognostic marker for cervical cancer in clinical practice.

\section{Targeting of epigenetic abnormalities in cervical cancer therapy}

A recent study demonstrated the efficacy of cisplatin combined with 5-azacytidine, which acts as a demethylating agent (51). Chemotherapy with cisplatin inhibited cervical cancer cells, but the same dose of cisplatin with added 5-azacytidine exerted a more potent inhibitory effect. Combination of another demethylating agent, 5-aza-2'-deoxycytidine, with taxol or cisplatin, also inhibited growth of drug-resistant cervical cancer cells (52), with taxol exerting a particularly strong effect. The standard of care for cervical cancer is a combination of paclitaxel and cisplatin. Therefore, potentiating the effects of these drugs and eliminating chemotherapy resistance are important clinical advances.

Combination therapy including tumor necrosis factor-related apoptosis-inducing ligand (TRAIL) is also effective (53). TRAIL is a cytokine in the tumor necrosis factor (TNF) family that induces apoptosis via its receptor in various human tumor cells, but not in normal cells. TNFRSF10C $(D c R 1)$ and TNFRSF10D (DcR2) are decoy receptors and multi-drug resistance (MDR) genes, and have been identified
Table I. Methylated genes in cervical cancer.

\begin{tabular}{llc}
\hline Gene name & \multicolumn{1}{c}{ Function } & $($ Refs.) \\
\hline TP73 & Apoptosis & $(4)$ \\
$F H I T$ & Apoptosis & $(3,5,7,15,16)$ \\
$D A P K 1$ & Apoptosis & $(3)$ \\
$P R D M 14$ & Apoptosis & $(6)$ \\
$C C N A 1$ & Cell cycle, DNA repair & $(8,9)$ \\
$D O C 2 B$ & Cell cycle & $(10)$ \\
$A P C$ & Wnt/ $\beta$ catenin pathway & $(11)$ \\
$S F R P$ & Wnt/ $\beta$ catenin pathway & $(12)$ \\
$F A N C F$ & DNA repair & $(13)$ \\
$M G M T$ & DNA repair & $(3,14,15)$ \\
$h M L H 1$ & DNA repair & $(15)$ \\
$F H I T$ & Cell growth & $(3,5,7,15,16)$ \\
$R A R-\beta$ & Cell growth & $(15,17)$ \\
$M A L$ & Cell growth & $(17)$ \\
$C X C R 4$ & Cell-cell adhesion & $(19)$ \\
$C A D M 1$ & Cell-cell adhesion & $(20)$ \\
\hline
\end{tabular}

Table II. Methylated genes in endometrial cancer.

\begin{tabular}{llc}
\hline Gene name & \multicolumn{1}{c}{ Function } & (Refs.) \\
\hline hMLH1 & DNA repair & $(22-26)$ \\
$M G M T$ & DNA repair & $(27)$ \\
$A P C$ & Wnt/ $\beta$ catenin pathway & $(25,28)$ \\
$C D H$ & Wnt/ $\beta$ catenin pathway & $(29,30)$ \\
E-cadherin & Wnt/ $\beta$ catenin pathway & $(25,29-32)$ \\
PTEN & Akt pathway & $(33)$ \\
RASSF1A & Apoptosis & $(30,34)$ \\
CASP8 & Apoptosis & $(35)$ \\
GSTP1 & Apoptosis & $(30,36)$ \\
$P 73$ & Apoptosis & $(33)$ \\
$P A R-4$ & Apoptosis & $(37)$ \\
SOX2 & Apoptosis & $(38)$ \\
$C H F R$ & Cell cycle checkpoint & $(39)$ \\
$P 14$ & Cell cycle checkpoint & $(40)$ \\
$P 16$ & Cell cycle checkpoint & $(40,41)$ \\
$A R$ & Receptor & $(42)$ \\
$P R$ & Receptor & $(43)$ \\
$R A R \beta$ & Receptor & $(44)$ \\
$T E S T I N$ & Epithelial-to-mesenchymal & $(45)$ \\
& transition & \\
$G A T A 4$ & Transcription factor & $(46)$ \\
TIMP3 & Proteasome system & $(47)$ \\
\hline
\end{tabular}

as epigenetically inactivated genes. TNFRSF10C methylation is found in precancerous lesions, which suggests that this is an early event in the cervical neoplastic process. Cervical cancer cells containing inactivated $D c R 1$ and $D c R 2$ exhibited increased TRAIL-induced apoptosis through activation of 
extrinsic apoptosis pathways (53). Therefore, patients without expression of decoy receptors are predicted to exhibit an enhanced response to combined therapy with TRAIL. This suggests that a strategy aimed at downregulating decoy receptors may be a feasible approach to treatment using TRAIL.

\section{Diagnosis of endometrial cancer and epigenetic abnormalities}

Endometrial cancer induced by epigenetic abnormalities is frequently caused by breakdown of the DNA mismatch repair (MMR) system. Under normal conditions, this system perceives DNA insertions and deletions, induces expression of repair enzymes, deletes affected DNA regions and resynthesizes damaged genes via DNA polymerases (54). If the MMR system is dysfunctional, DNA replication mistakes are not repaired and microsatellites (repeats of 1-5 bases) are likely to increase or decrease. This condition is referred to as microsatellite instability (MSI). MMR genes may be abnormally methylated and cancer develops when MSI occurs in regions of tumor suppressor genes. Numerous microsatellites are detectable by PCR and are found in 20-40\% of cases of endometrial cancer (22,55-57).

Genes involved in the MMR system include $h M L H 1$, MutS protein homolog 2 ( $h M S H 2)$ and $h M S H 6$, and postmeiotic segregation increased 2 ( $h P M S 2)$ is frequently abnormally methylated (56). $h M L H 1$ methylation has been found in $40.1 \%$ of cases of endometrial cancer and in $14.3 \%$ of cases of atypical endometrial hyperplasia, a precancerous endometrial lesion; therefore, abnormal methylation of $h M L H 1$ is considered to be significantly involved in carcinogenesis (43).

A recent study of cullin-5 (CUL5) demonstrated that this gene is involved in breast and cervical cancer and hepatocellular carcinoma. CUL5 was significantly downregulated in serous endometrial adenocarcinoma with a poor prognosis, compared with its level in endometrial carcinoma with a good prognosis (58). The action of CUL5 involves non-coding RNAs (ncRNAs), which are RNAs that do not include genetic information for protein synthesis. These include microRNAs (miRNAs) of 18-25 nucleotides that lead to mature miRNAs that bind to the 3'-untranslated region (UTR) of target genes and inhibit gene function (46). Two highly-conserved miR-182-binding regions are present in the 3'-UTR of CUL5, and CUL5 targets miR-182 in endometrial cancer. CUL5 downregulation causes miR-182 upregulation and progression of endometrial cancer (58). Zhou et al demonstrated that miR-30c overexpression inhibited metastasis-associated gene-1 (MTA1) (59). miR-30c is decreased in endometrial, ovarian, breast and gastric cancer (60-63) and it is involved in carcinogenesis through its association with MTAl.

\section{Targeting of epigenetic abnormalities in endometrial cancer therapy}

Unlike genetic changes, epigenetic alterations are not irreversible, and it may be possible to use molecular-targeted drugs to induce transcription of tumor suppressor genes via demethylation (64). The effects of demethylating drugs on tumor suppression include inhibition of growth of cervical cancer cells in vivo by demethylation of $A P C$ by hydralazine (65) and 5-azacytidine-induced expression of $A P C$ and $h M L H 1$ in endometrial cancer in vitro (22). With regard to treatment of epigenetic changes by miRNAs, Tsuruta et al demonstrated in vivo and in vitro that exogenous miR-152 targeting of DNA methyltransferase 1 (DNMT1) in endometrial cancer cells without expression of miR-152 inhibited tumor proliferation (66). Zhao et al recently reported similar results for miR-126 targeting of insulin receptor substrate 1 (67). These results suggest that cancer therapy may be established by delivery of dsRNA.

DNMTs and histone deacetylases (HDACs) are key enzymes mediating epigenetic regulation of gene expression. The majority of events involving DNA overexpression and histone deacetylation in promoter regions are associated with transcriptional downregulation or silencing, and epigenetic silencing of tumor suppressor genes plays an important role in malignant transformation (68). DNMT inhibitors induce DNA demethylation and HDAC inhibitors cause histone acetylation, resulting in reactivation of silenced genes and functional and morphological changes in cancer cells. DNMT inhibitor-mediated demethylation of the cadherin $(C D H) 1$ promoter results in upregulation of $E$-cadherin in endometrial cancer cells. A combination of DNMT and HDAC inhibitors upregulated CDH1 and downregulated B-cell lymphoma 2 at the mRNA level, inducing cell cycle arrest and apoptosis (69). This combination has a synergistic effect and is likely to become a new treatment for endometrial cancer.

\section{Conclusion}

In uterine cancer, epigenetic and genetic changes are intertwined in a complex manner, resulting in cancer onset. Epigenetic changes cause phenomena including inhibition of apoptosis, DNA repair inhibition, overgrowth and enhanced cancer growth. Genes involved in epigenetic changes are inhibited by methylation, and reactivation of these genes may inhibit the growth of cancer cells. Epigenetic information may also be useful in screening for uterine cancer with high sensitivity and specificity and for development of novel molecular-targeted drugs, leading to improved treatment outcomes in uterine and other cancers. Therefore, further studies on cancer epigenetics are essential for improvement of cancer therapy.

\section{References}

1. Ferlay J, Soerjomataram I, Ervik M, Dikshit R, Eser S, Mathers C, Rebelo M, Parkin DM, Forman D and Bray F: GLOBOCAN 2012 v1.1, Cancer Incidence and Mortality Worldwide: IARC CancerBase No. 11 (Internet). Lyon, France: International Agency for Research on Cancer; 2014. Available from: http://globocan. iarc.fr. Accessed on August 10, 2016.

2. Bhat S, Kabekkodu SP, Noronha A and Satyamoorthy K: Biological implications and therapeutic significance of DNA methylation regulated genes in cervical cancer. Biochimie 121: 298-311, 2016.

3. Banzai C, Nishino K, Quan J, Yoshihara K, Sekine M, Yahata T and Tanaka K; Gynecological Cancer Registry of Niigata: Promoter methylation of DAPK1, FHIT, MGMT, and CDKN2A genes in cervical carcinoma. Int J Clin Oncol 19: 127-132, 2014.

4. Liu SS, Leung RC, Chan KY, Chiu PM, Cheung AN, Tam KF, Ng TY, Wong LC and Ngan HY: p73 expression is associated with the cellular radiosensitivity in cervical cancer after radiotherapy. Clin Cancer Res 10: 3309-3316, 2004.

5. Roz L, Gramegna M, Ishii H, Croce CM and Sozzi G: Restoration of fragile histidine triad (FHIT) expression induces apoptosis and suppresses tumorigenicity in lung and cervical cancer cell lines. Proc Natl Acad Sci USA 99: 3615-3320, 2002. 
6. Snellenberg S, Cillessen SA, Van Criekinge W, Bosch L, Meijer CJ,Snijders PJ and Steenbergen RD: Methylation-mediated repression of PRDM14 contributes to apoptosis evasion in HPV-positive cancers. Carcinogenesis 35: 2611-2618, 2014.

7. Wu Q, Shi H, Suo Z and Nesland JM: 5'-CpG island methylation of the FHIT gene is associated with reduced protein expression and higher clinical stage in cervical carcinomas. Ultrastruct Pathol 27: 417-422, 2003.

8. Kitkumthorn N, Yanatatsanajit P, Kiatpongsan S, Phokaew C, Triratanachat $\mathrm{S}$, Trivijitsilp $\mathrm{P}$, Termrungruanglert $\mathrm{W}$ Tresukosol D, Niruthisard S and Mutirangura A: Cyclin A1 promoter hypermethylation in human papillomavirus-associated cervical cancer. BMC Cancer 6: 55, 2006.

9. Chujan S, Kitkumthorn N, Siriangkul S and Mutirangura A: CCNA1 promoter methylation: A potential marker for grading Papanicolaou smear cervical squamous intraepithelial lesions. Asian Pac J Cancer Prev 15: 7971-7975, 2014.

10. Kabekkodu SP, Bhat S, Radhakrishnan R, Aithal A, Mascarenhas R, Pandey D, Rai L, Kushtagi P, Mundyat GP and Satyamoorthy K: DNA promoter methylation-dependent transcription of the double C2-like domain $\beta$ (DOC2B) gene regulates tumor growth in human cervical cancer. J Biol Chem 289: 10637-10649, 2014.

11. Aoki K and Taketo MM: Adenomatous polyposis coli (APC): A multi-functional tumor suppressor gene. J Cell Sci 120 3327-3335, 2007

12. Lin YW, Chung MT, Lai HC, De Yan M, ShihYL, Chang CC and $\mathrm{Yu} \mathrm{MH}$ : Methylation analysis of SFRP genes family in cervical adenocarcinoma. J Cancer Res Clin Oncol 135: 1665-1674, 2009

13. Narayan G, Arias-Pulido H, Nandula SV, Basso K, Sugirtharaj DD, Vargas H, Mansukhani M, Villella J, Meyer L, Schneider A, et al: Promoter hypermethylation of FANCF: Disruption of Fanconi Anemia-BRCA pathway in cervical cancer. Cancer Res 64: 2994-2997, 2004.

14. Henken FE, Wilting SM, Overmeer RM, van Rietschoten JG, Nygren AO, Errami A, Schouten JP, Meijer CJ, Snijders PJ and Steenbergen RD: Sequential gene promoter methylation during HPV-induced cervical carcinogenesis. Br J Cancer 97 $1457-1464,2007$

15. Virmani AK, Muller C, Rathi A, Zoechbauer-Mueller S Mathis $\mathrm{M}$ and Gazdar AF: Aberrant methylation during cervical carcinogenesis. Clin Cancer Res 7: 584-589, 2001.

16. Bai LX, Wang JT, Ding L, Jiang SW, Kang HJ, Gao CF, Chen X, Chen $\mathrm{C}$ and Zhou Q: Folate deficiency and FHIT hypermethylation and HPV 16 infection promote cervical cancerization. Asian Pac J Cancer Prev 15: 9313-9317, 2014.

17. Ivanova T, Petrenko A, Gritsko T, Vinokourova S, Eshilev E, Kobzeva V, Kisseljov F and Kisseljova N: Methylation and silencing of the retinoic acid receptor-beta 2 gene in cervical cancer. BMC Cancer 2: 4, 2002.

18. De Strooper LM, vanZummeren M, Steenbergen RD, Bleeker MC, Hesselink AT, Wisman GB, Snijders PJ, Heideman DA and Meijer CJ: CADM1, MAL and miR124-2 methylation analysis in cervical scrapes to detect cervical and endometrial cancer. J Clin Pathol 67: 1067-1071, 2014.

19. Kim JH, Choi YD, Lee JS, Lee JH, Nam JH and Choi C: Assessment of DNA methylation for the detection of cervical neoplasia in liquid-based cytology specimens. Gynecol Oncol 116: 99-104, 2010

20. Yadav SS, Prasad SB, Das M, Kumari S, Pandey LK, Singh S Pradhan S and Narayan G: Epigenetic silencing of CXCR4 promotes loss of cell adhesion in cervical cancer. Biomed Res Int 2014: 581403, 2014.

21. Overmeer RM, Henken FE, Snijders PJ, Claassen-Kramer D, Berkhof J, Helmerhorst TJ, Heideman DA, Wilting SM, Murakami Y, Ito A, et al: Association between dense CADM1 promoter methylation and reduced protein expression in high-grade CIN and cervical SCC. J Pathol 215: 388-397, 2008.

22. Bischoff J, Ignatov A, Semczuk A, Schwarzenau C, Ignatov T, Krebs T, Küster D, Przadka-Rabaniuk D, Roessner A, Costa SD and Schneider-Stock R: hMLH1 promoter hypermethylation and MSI status in human endometrial carcinomas with and without metastases. Clin Exp Metastasis 29: 889-900, 2012.

23. Guida M, Sanguedolce F, Bufo P, Di Spiezio Sardo A, Bifulco G, Nappi $\mathrm{C}$ and Pannone G: Aberrant DNA hypermethylation of hMLH-1 and CDKN2A/p16 genes in benign, premalignant and malignant endometrial lesions. Eur J Gynaecol Oncol 30: 267-270, 2009

24. Pallarés J, Velasco A, Eritja N, Santacana M, Dolcet X, Cuatrecasas M, Palomar-Asenjo V, Catasús L, Prat J and Matias-Guiu X: Promoter hypermethylation and reduced expression of RASSF1A are frequent molecular alterations of endometrial carcinoma. Mod Pathol 21: 691-699, 2008.
25. Banno K, Yanokura M, Susumu N, Kawaguchi M, Hirao N, Hirasawa A, Tsukazaki K and Aoki D: Relationship of the aberrant DNA hypermethylation of cancer-related genes with carcinogenesis of endometrial cancer. Oncol Rep 16: 1189-1196, 2006.

26. Jo H, Kim JW, Kang GH, Park NH, Song YS, Kang SB and Lee HP: Association of promoter hypermethylation of the RASSF1A gene with prognostic parameters in endometrial cancer. Oncol Res 16: 205-209, 2006.

27. Lee KE: Immunohistochemical assessment of $\mathrm{O}(6)$ methylguanine-DNA methyltransferase (MGMT) and Its relationship with p53 expression in endometrial cancers. J Cancer Prev 18: 351-354, 2013.

28. Ignatov A,BischoffJ,Ignatov T,Schwarzenau C,Krebs T, KuesterD, Costa SD, Roessner A, Semczuk A and Schneider-Stock R: APC promoter hypermethylation is an early event in endometrial tumorigenesis. Cancer Sci 101: 321-327, 2010.

29. Suehiro Y, Okada T, Okada T, Anno K, Okayama N, Ueno K, Hiura M, Nakamura M, Kondo T, Oga A, et al: Aneuploidy predicts outcome in patients with endometrial carcinoma and is related to lack of CDH13 hypermethylation. Clin Cancer Res 14: 3354-3361, 2008

30. Fiolka R, Zubor P, Janusicova V, Visnovsky J, Mendelova A, Kajo K, Lasabova Z, Plank L and Danko J: Promoter hypermethylation of the tumor-suppressor genes RASSF1A, GSTP1 and CDH1 in endometrial cancer. Oncol Rep 30: 2878-2886, 2013.

31. Park JH, Lee BI, Song ES, Whang SO, Lee WY and Cho SJ: Hypermethylation of E-cadherin in endometrial carcinoma. J Gynecol Oncol 19: 241-245, 2008.

32. Saito T,Nishimura M, YamasakiH and Kudo R: Hypermethylation in promoter region of E-cadherin gene is associated with tumor dedifferention and myometrial invasion in endometrial carcinoma. Cancer 97: 1002-1009, 2003.

33. Yang HJ, Liu VW, Wang Y, Tsang PC and Ngan HY: Differential DNA methylation profiles in gynecological cancers and correlation with clinico-pathological data. BMC Cancer 6: 212, 2006.

34. Kang S, Lee JM, Jeon ES, Lee S, Kim H, Kim HS, Seo SS, Park SY, Sidransky D and Dong SM: RASSF1A hypermethylation and its inverse correlation with BRAF and/or KRAS mutations in MSI-associated endometrial carcinoma. Int J Cancer 119: 1316-1321, 2006.

35. Sánchez-Vega F, Gotea V, Petrykowska HM, Margolin G, Krivak TC, DeLoia JA, Bell DW and Elnitski L: Recurrent patterns of DNA methylation in the ZNF154, CASP8 and VHL promoters across a wide spectrum of human solid epithelial tumors and cancer cell lines. Epigenetics 8: 1355-1372, 2013.

36. Chan QK, Khoo US, Chan KY, Ngan HY, Li SS, Chiu PM, Man LS, Ip PP, Xue WC and Cheung AN: Promoter methylation and differential expression of pi-class glutathione S-transferase in endometrial carcinoma. J Mol Diagn 7: 8-16, 2005.

37. Moreno-Bueno G, Fernandez-Marcos PJ, Collado M, Tendero MJ, Rodriguez-Pinilla SM, Garcia-Cao I, Hardisson D, Diaz-Meco MT, Moscat J, Serrano M and Palacios J: Inactivation of the candidate tumor suppressor par-4 in endometrial cancer. Cancer Res 67: 1927-1934, 2007.

38. Wong OG, Huo Z, Siu MK, Zhang H, Jiang L, Wong ES and Cheung AN: Hypermethylation of SOX2 promoter in endometrial carcinogenesis. Obstet Gynecol Int 2010: pii:682504, 2010.

39. Muraki Y, Banno K, Yanokura M, Kobayashi Y, Kawaguchi M, Nomura H, Hirasawa A, Susumu N and Aoki D: Epigenetic DNA hypermethylation: Clinical applications in endometrial cancer (Review). Oncol Rep 22: 967-972, 2009.

40. Zhang QY, Yi DQ, Zhou L, Zhang DH and Zhou TM: Status and significance of $\mathrm{CpG}$ island methylator phenotype in endometrial cancer. Gynecol Obstet Invest 72: 183-191, 2011.

41. Semczuk A, Boltze C, Marzec B, Szczygielska A, Roessner A and Schneider-Stock R: p16INK4A alterations are accompanied by aberrant protein immunostaining in endometrial carcinomas. J Cancer Res Clin Oncol 129: 589-596, 2003.

42. Sasaki M, Oh BR, Dharia A, Fujimoto S and Dahiya R: Inactivation of the human androgen receptor gene is associated with $\mathrm{CpG}$ hypermethylation in uterine endometrial cancer. Mol Carcinog 29: 59-66, 2000

43. Sasaki M, Dharia A, Oh BR, Tanaka Y, Fujimoto S and Dahiya R: Progesterone receptor B gene inactivation and $\mathrm{CpG}$ hypermethylation in human uterine endometrial cancer. Cancer Res 61: 97-102, 2001.

44. Li R, Saito T, Tanaka R, Satohisa S, Adachi K, Horie M, Akashi Y and Kudo R: Hypermethylation in promoter region of retinoic acid receptor-beta gene and immunohistochemical findings on retinoic acid receptors in carcinogenesis of endometrium. Cancer Lett 219: 33-40, 2005 
45. Dong R, Pu H, Wang Y, Yu J, Lian K and Mao C: TESTIN was commonly hypermethylated and involved in the epithelial-mesenchymal transition of endometrial cancer. APMIS 123: 394-400, 2015.

46. Chmelarova M, Kos S, Dvorakova E, Spacek J, Laco J, Ruszova E, Hrochova $\mathrm{K}$ and Palicka V: Importance of promoter methylation of GATA4 and TP53 genes in endometrioid carcinoma of endometrium. Clin Chem Lab Med 52: 1229-1234, 2014.

47. Catasus L, Pons C, Muñoz J, Espinosa I and Prat J: Promoter hypermethylation contributes to TIMP3 down-regulation in high stage endometrioid endometrial carcinomas. Histopathology 62: 632-641, 2013

48. Boers A, Wang R, van Leeuwen RW, Klip HG, de Bock GH, Hollema H, van Criekinge W, de Meyer T, Denil S, van der Zee AGJ, et al: Discovery of new methylation markers to improve screening for cervical intraepithelial neoplasia grade $2 / 3$. Clin Epigenetics 8: 29, 2016.

49. Zhang LY, Han CS, Li PL and Zhang XC: 5-Hydroxymethylcytosine expression is associated with poor survival in cervical squamous cell carcinoma. Jpn J Clin Oncol 46: 427-434, 2016.

50. Iyer LM, Tahiliani M, Rao A and Aravind L: Prediction of novel families of enzymes involved in oxidative and other complex modifications of bases in nucleic acids. Cell Cycle 8: 1698-1710, 2009.

51. Sood S and Srinivasan R: Alterations in gene promoter methylation and transcript expression induced by cisplatin in comparison to 5-azacytidine in $\mathrm{HeLa}$ and $\mathrm{SiHa}$ cervical cancer cell lines. Mol Cell Biochem 404: 181-191, 2015.

52. Chen CC, Lee KD, Pai MY, Chu PY, Hsu CC, Chiu CC, Chen LT, Chang JY, Hsiao SH and Leu YW: Changes in DNA methylation are associated with the development of drug resistance in cervical cancer cells. Cancer Cell Int 15: 98, 2015.

53. Narayan G, Xie D, Ishdorj G, Scotto L, Mansukhani M, Pothuri B, Wright JD, Kaufmann AM, Schneider A, Arias-Pulido H and Murty VV: Epigenetic inactivation of TRAIL decoy receptors at $8 \mathrm{p} 12-21.3$ commonly deleted region confers sensitivity to Apo2L/trail-Cisplatin combination therapy in cervical cancer. Genes Chromosomes Cancer 55: 177-189, 2016.

54. Jascur T and Boland CR: Structure and function of the components of the human DNA mismatch repair system. Int J Cancer 119: 2030-2035, 2006.

55. Eto T, Zhao Y, Maruyama A, Miyashita K, Yasui A, Nakao S, Taguchi K, Shimokawa M, Oda S and Saito T: Modal variety of microsatellite instability in human endometrial carcinomas. J Cancer Res Clin Oncol 142: 353-363, 2016.

56. Bilbao C, Lara PC, Ramírez R, Henríquez-Hernández LA, Rodríguez G, Falcón O, León L, Perucho M, Díaz-Chico BN and Díaz-Chico JC: Microsatellite instability predicts clinical outcome in radiation-treated endometrioid endometrial cancer. Int J Radiat Oncol Biol Phys 76: 9-13, 2010.

57. Hampel H, Frankel W, Panescu J, Lockman J, Sotamaa K, Fix D, Comeras I, La Jeunesse J, Nakagawa H, Westman JA, et al: Screening for Lynch syndrome (hereditary nonpolyposis colorectal cancer) among endometrial cancer patients. Cancer Res 66: 7810-7817, 2006.

58. Devor EJ, Schickling BM, Reyes HD, Warrier A, Lindsay B, Goodheart MJ, Santillan DA and Leslie KK: Cullin-5, a ubiquitin ligase scaffold protein, is significantly underexpressed in endometrial adenocarcinomas and is a target of miR-182. Oncol Rep 35: 2461-2465, 2016.

59. Zhou H, Xu X, Xun Q, Yu D, Ling J, Guo F, Yan Y, Shi J and Hu Y: microRNA-30c negatively regulates endometrial cancer cells by targeting metastasis-associated gene-1. Oncol Reports 27 : $807-812,2012$.
60. Boren T, Xiong Y, Hakam A, Wenham R, Apte S, Wei Z, Kamath S, Chen DT, Dressman H and Lancaster JM: MicroRNAs and their target messenger RNAs associated with endometrial carcinogenesis. Gynecol Oncol 110: 206-215, 2008.

61. Lee H, Park CS, Deftereos G, Morihara J, Stern JE, Hawes SE, Swisher E, Kiviat NB and Feng Q: MicroRNA expression in ovarian carcinoma and its correlation with clinicopathological features. World J Surg Oncol 10: 174, 2012

62. Li S, Yang C, Zhai L, Zhang W, Yu J, Gu F, Lang R, Fan Y, Gong M, Zhang $X$ and Fu L: Deep sequencing reveals small RNA characterization of invasive micropapillary carcinomas of the breast. Breast Cancer Res Treat 136: 77-87, 2012.

63. Ueda T, Volinia S, Okumura H, Shimizu M, Taccioli C, Rossi S, Alder H, Liu CG, Oue N, Yasui W, et al: Relation between microRNA expression and progression and prognosis of gastric cancer: A microRNA expression analysis. Lancet Oncol 11: 136-146, 2010.

64. Duenas-Gonzalez A, Medina-Franco JL, Chavez-Blanco A, Dominguez-Gomez G and Fernández-de Gortari E: Developmental DNA methyltransferase inhibitors in the treatment of gynecologic cancers. Expert Opin Pharmacother 17: 323-338, 2016.

65. Song Y and Zhang C: Hydralazine inhibits human cervical cancer cell growth in vitro in association with APC demethylation and re-expression. Cancer Chemother Pharmacol 63: 605-613, 2009.

66. Tsuruta T, Kozaki K, Uesugi A, Furuta M, Hirasawa A, Imoto I, Susumu N, Aoki D and Inazawa J: miR-152 is a tumor suppressor microRNA that is silenced by DNA hypermethylation in endometrial cancer. Cancer Res 71: 6450-6462, 2011.

67. Zhao X, Zhu D, Lu C, Yan D, Li L and Chen Z: MicroRNA-126 inhibits the migration and invasion of endometrial cancer cells by targeting insulin receptor substrate 1. Oncol Lett 11: 1207-1212, 2016.

68. Ren J, Zhang J, Cai H, Li Y, Zhang Y, Zhang X, Zhao D, Li Z, $\mathrm{Ma} \mathrm{H}$, Wang J, et al: HDAC as a therapeutic target for treatment of endometrial cancers. Curr Pharm Des 20: 1847-1856, 2014.

69. Yi TZ, Li J, Han X, Guo J, Qu Q, Guo L, Sun HD and Tan WH: DNMT inhibitors and HDAC inhibitors regulate E-cadherin and bcl-2 expression in endometrial carcinoma in vitro and in vivo. Chemotherapy 58: 19-29, 2012. 